\title{
Tolerancja jako wartość i cel w edukacji wielo- i międzykulturowej dziecka w młodszym wieku szkolnym
}

Streszczenie: Kwestia edukacji ku tolerancji w aktualnej rzeczywistości świata bez granic jest wciąż ważnym zagadnieniem. Jest ona wartością priorytetową, wpisaną w cele edukacji wielo- i międzykulturowej. Dzięki temu stajemy się społeczeństwem otwartym. Dlatego też w artykule tym poruszone i omówione zostają zagadnienia dotyczące pojęcia tolerancji, jej zakresów i wymiarów w odniesieniu do założeń edukacji międzykulturowej. Na podstawie uzyskanych opinii nauczycieli podjęta została problematyka tolerancji dziecka w młodszym wieku szkolnym w zakresie przejawiania postaw protolerancyjnych oraz czynników warunkujących dziecięcą nietolerancję.

Słowa kluczowe: tolerancja, wielokulturowość, edukacja międzykulturowa, edukacja wczesnoszkolna

\section{Wprowadzenie}

Wychowanie do tolerancji oraz kształtowanie postaw protolerancyjnych jest jednym z podstawowych celów edukacyjnych, gdyż zawiera w sobie aspekt wielokulturowości oraz aksjologicznego kształtowania moralnej sylwetki jednostek ludzkich. Przemiany społeczno-kulturowe, zaistniałe we współczesnych społeczeństwach, propagują idę globalizacji. W jej następstwie ludzkość ma stanowić otwartą wspólnotę, co implikuje międzykulturowy wymiar tolerancji. Fakt ten z kolei idzie w parze z koniecznością edukacji ku wartościom wyższym, jak szacunek i prawda, sprzyjając przyzwoleniu na odmienność. Jej dostrzeganie powinno mieć miejsce zarówno w wymiarze jednostkowym, jak i społecznym, pomimo biologicznie uwarunkowanego zakorzenienia w kulturze.

Tolerancja oraz wielokulturowość tworzą na tym etapie całość, łącząc w sobie motywy akceptacji, demokratyzacji życia społecznego i pokojowej 
koegzystencji społeczeństw, która osadzona jest w perspektywie historycznej. W następstwie wojen religijnych w XVI oraz XVII wieku ukazywały się pierwsze traktaty o tolerancji. W skali Polski podstawą propagowania powyższej wartości stała się nie tylko burzliwa historia, ale również decentralizacja kraju i związany z nią fakt mieszania się wyznań oraz kultur. Jak pisze Hanna Hamer, „trudno byłoby wymienić inny katolicki kraj w XVI i XVII wieku, w którym przeciwnicy panującego Kościoła korzystaliby z tak wszechstronnej swobody, jak w Rzeczpospolitej Polskiej" ${ }^{1}$. Nawet czasy walki arian z innowiercami nie wykorzeniły w Polakach jej przejawów, czego dowodem było w 1773 roku zniesienie przez Sejm RP większości ustaw dyskryminujących „różnowierców”. Z kolei Konstytucja 3 maja z 1791 roku przyniosła mniejszościom narodowym pełnię praw obywatelskich i swobodę wyznań, wypełniając zalecenia Komisji Edukacji Narodowej ${ }^{2}$. Wskazywano na jej zalety i negowano podtrzymywany przez kontrreformację sąd, iż wartość ta jest czynnikiem powodującym upadek korzeni polskości, a tym samym kraju3.

Zgodnie z postulatami przyjętej 16 listopada 1995 roku przez Konfederację Generalną w Paryżu Deklaracji Zasad Tolerancji jest ona wartością pozytywną, a nie formą protekcjonalności czy ustępstwa, lecz postawą łączącą w sobie elementy wzajemnego zrozumieniu i szacunku ${ }^{4}$. Również współczesna wizja świata bez granic wzmaga społeczny dyskurs wobec jej edukacyjnej rangi, czyniąc powyższą wartość priorytetową $\mathrm{w}$ dobie kulturowego zróżnicowania narodu polskiego. W związku z tym „przygotowanie do budowania międzykulturowości” przybiera formę „społecznego zamówienia”, które egzekwuje kształtowanie postawy tolerancji ${ }^{5}$. Powyższa zależność implikuje współistnienie „ze sobą” a nie „obok siebie”. Powołując się w tym miejscu na słowa Michaela Walzera, „tolerowanie i bycie tolerowanym przypomina trochę »Arystotelesowskie« rządzenie i bycie rządzonym" ". Jest to przejaw funkcjonowania człowieka w obecnym systemie demokratycznym ${ }^{8}$. Dlatego tolerancja staje się walorem koniecz-

1 H. Hamer: Demon nietolerancji. Warszawa 1994, WSiP, s. 111-114.

2 Tamże.

3 Tamże, s. 110-114.

4 V. Kopińska: Kilka uwag o tolerancji. „Wychowanie na co dzień” 2008, nr 3, s. 7.

5 A. Młynarczuk, M.M. Sokołowski: Ze sobq a nie obok siebie (edukacja równoległa w procesie ksztattowania postaw tolerancji. „Nowa Szkoła” 2008, nr 5, s. 11.

6 Tamże.

7 M. Walzer: O tolerancji. Warszawa 1999, PIW, s. 9-10.

8 Tamże, s. 9. 
nym w budowaniu pozytywnych relacji międzyludzkich, gdyż warunkuje ona społeczne przyzwolenie na kulturową różnorodność.

\section{Znaczenie i zakres pojęcia tolerancji}

Tolerancja w swym etymologicznym znaczeniu wywodzi się od łacińskiego słowa tolerantia, co oznacza wyrozumiałość ${ }^{9}$. Natomiast jej konceptualizacja pojęciowa jest różnorodna pod względem terminologicznym i definicyjnym. W literaturze przedmiotu określona jest ona jako aprobata wobec odmiennych niż nasze przekonań, sposobu myślenia lub postępowania, o ile nie zagrażają one dobru ogółu i nie ingerują w godność osoby ludzkiej ${ }^{10}$. W związku z tym, dokonano jej rozgraniczenia na tolerancję umysłową (respektowanie prawa innych do wyrażania własnych poglądów), moralną (uznawanie odmiennego stylu życia i zachowania) oraz religijną (jako nieprzymuszona i nienarzucona wolność wyznania i światopoglądu ${ }^{11}$. Tolerancyjny jest człowiek, który dostrzega w bliźnim uczestnika dialogu, a nie swego wroga ${ }^{9}$. Zależność ta pozawala ludzkości zatrzeć granice, pokonać mur uwarunkowanych kulturowo stereotypów i uprzedzeń. Poprzez to społeczeństwo otwiera się na inność. Jednak sama postawa tolerancji nie wymusza na jednostkach, aby zgadzały się z odmiennymi poglądami, zasadami lub upodobaniami. Toteż jej pragmatyczny wymiar łączy się - w ujęciu Jerzego Nikitorowicza - z dialogiem i negocjacją, które stanowią integralne aspekty relacji międzyludzkich na pograniczu kultur ${ }^{12}$. Warunkują one równouprawnienie, dążąc do obrony i zachowania godności osoby ludzkiej, jako członka społeczeństwa ${ }^{13}$. To poszanowanie dokonanych przez drugą osobę relatywnie moralnych, życiowych wyborów, nawet tych sprzecznych z naszymi przekonaniami ${ }^{14}$.

W rozważaniach na temat tolerancji Katarzyna Szewetowska w jednym ze swym artykułów wyróżnia dwa jej zakresy: wąski oraz szeroki. Pierwszy z nich

9 W. Okoń: Nowy stownik pedagogiczny. Warszawa 1998, Wydawnictwo Akademickie „Żak”, s. 405.

10 M. Łobocki: W trosce o wychowanie w szkole. Kraków 2009, Oficyna Wydawnicza „Impuls”, s. 70.

11 J. Nikitorowicz: Tolerancja idea i cel edukacji międzykulturowej. „Problemy Opiekuńczo-Wychowawcze" 1995, nr 6, s. 3.

12 Tamże.

13 Tamże.

14 R. Krajewski: Czy katolik może być tolerancyjny? „Znak” 2007, nr 11, s. 60. 
autorka interpretuje jako brak sprzeciwu wobec poglądów i działań jednostki lub społeczeństwa ${ }^{15}$. Zakres szeroki obejmuje bezsilności w stosunku do określonych sytuacji sprawiających nam przykrość oraz zawiera on motyw uległości i zgody na działanie jednostek lub grup godzących w struktury psychiczne obserwatora ${ }^{16}$. W literaturze przedmiotu znajdujemy także trzy znaczenia pojęcia tolerancji, jako wartości pozytywnej, negatywnej oraz braku przymusu. Pierwsze z nich, a więc tolerancja jako wartość negatywna, jest formą słabsza, pasywnq ${ }^{17}$. Polega ona na samym znoszeniu odmienności ${ }^{18}$. Oznacza zatem bierność opinii, brak interwencji wobec czyichś zachowań, mimo ich negatywnej oceny przez osobę tolerancyjną ${ }^{19}$. Człowiek akceptuje więc poglądy swego partnera, chociaż są odmienne w stosunku do jego przekonań, bo tak mu wygodnie. Ija Lazari-Pawłowska jako motywy powyższej pasywności podaje: obojętność, poczucie przewagi nad innymi oraz pragnienie harmonijnego współżycia społecznego ${ }^{20}$. Jednostka nie podejmuje żadnych działań, aby mieć tzw. święty spokój pomimo tego, że czyjeś drażniące zachowanie godzi w jej godność oraz jest powodem stresów w codziennym życiu ${ }^{21}$. Natomiast tolerancja jako wartość pozytywna została poddana analizie przez Marię Ossowską, która uznaje ją za swoistą umiejętność szanowania odmiennych opinii i sądów, wywodzących się z szacunku wobec człowieka je wyrażającego, który staje się wówczas kimś godnym, wyjątkowym, posiadającym prawo do własnego zdania ${ }^{22}$. W ujęciu Ewy Podrez tolerancja jako wartość pozytywna stanowi formę krytycznego odniesienia się do tolerancji negatywnej, będąc swoistym wyrazem uznania i szacunku wobec autonomii jednostki ludzkiej².

15 K. Szewetowska: Tolerancja-zjawisko społeczne czy postawa? „Edukacja i Dia$\log " 2007$, nr 5, s. 51.

16 Tamże.

17 P. Mazurkiewicz: Tolerancja błogosławieństwo czy przekleństwo. „Społeczeństwo Otwarte" 1996, nr 10, s. 11.

18 Tamże.

19 I. Rudek: Od niechęci do akceptacji. O wychowaniu dzieci do tolerancji wobec osób niepełnosprawnych. Kraków 2008, Oficyna Wydawnicza „Impuls”, s. 75.

20 Za: J. Górniewicz: Kategorie pedagogiczne. Olsztyn 2001, UWM, s. 62.

21 Tamże.

22 Tamże, s. 51.

23 E. Podrez: Moralna ocena tolerancji. Tolerancja negatywna i pozytywna. W: A. Borowiak, P. Szarota (red.): Tolerancja i Wielokulturowość. Wyzwania XXI wieku. Warszawa 2004, SWPS „Academica”, s. 23. 
W sytuacji, kiedy człowiek tolerancyjny pozwala we wzajemnych relacjach swemu partnerowi na swobodne wyrażanie myśli i stwarza ku temu warunki, mamy do czynienia z tolerancją jako brakiem przymusu ${ }^{24}$. Interakcje międzyludzkie są wówczas oparte na dialogu, w którym brak jest uprzedzeń na tle kulturowym, etnicznym czy religijnym. Natomiast przedmiotem tolerancji staje się tutaj zachowanie polegające na wyrzeczeniu się prób korygującego działania na oponenta ${ }^{25}$. Wszelka ingerencja opiera się jedynie na metodach argumentacji i perswazji ${ }^{26}$. Dochodzi zatem do zatarcia granicy pomiędzy akceptacją a tolerowaniem, która przybiera formę liberalnej akceptacji ${ }^{27}$.

Należy jednak podkreślić, że istnieją pewne ideologiczne i moralne uwarunkowania, które wynikają ze społecznie nieakceptowanych, patologicznych zachowań, godzących w dobro jednostki ludzkiej. Rodzą one poczucie krzywdy oraz niesprawiedliwości i w związku z tym nie mogą być tolerowane. Trzeba tutaj zwrócić uwagę, iż przejmujemy z innych kultur nie tylko wartości pozytywne, lecz także negatywne, które stanowią zagrożenie dla moralnej sylwetki ludzkości. Dlatego też z tych wyborów wyłania się pytanie o istnienie granic tolerowania odmienności, która niejednokrotnie jest źródłem eskalacji zła. Stanowią one uwarunkowane biologicznie, racjonalne możliwości osoby ludzkiej, jako istoty kierującej się rozumem, osadzonej w zmieniającej się w czasie rzeczywistości społeczno-kulturowej ${ }^{28}$. W literaturze przedmiotu ujmuje się je w kategorii granic tolerancji2 ${ }^{29}$. Dookreślają one istotę tolerancji, opierając się na kryteriach prawdy, nienaruszalności dobra i poszanowania praw jednostki ludzkiej ${ }^{30}$. Uwarunkowane są one przez nasze wewnętrzne poczucie krzywdy względem innych jednostek, pogwałcenie podstawowych wartości oraz wolności i praw osoby ludzkiej, presję fizyczną, która zaburza

24 K. Sędziak-Paździora: Tolerancja i granice tolerancji. A. Rosół, M. Szczepański (red.): W: Tolerancja IV studia i szkice. Częstochowa 1997, WSP, s 50.

25 Tamże.

26 Tamże.

27 G. Gajewska: Granice tolerancji. Konteksty pedagogiczne. W: G. Gajewska, A. Szczęsna, E. Rewińska (red.): Wychowanie do tolerancji. Teoretyczno-metodyczne aspekty warsztatu pedagoga. Zielona Góra 2006, PEKW „GAJA”, s. 19.

28 Tamże, s. 25.

29 E. Wysocka: Religijność a tolerancja. Obszary zależności. Kraków 2000, „Nomos”, S. 50.

30 Tamże. 
słownq perswazję, oraz dialog pomiędzy jednostkami ${ }^{31}$. Tworzą one zatem indywidualnie zakreślone i przyjęte przez daną osobę normy ${ }^{32}$. Odwołując się w tym miejscu do słów ks. Józefa Tischnera, „człowiek jest w swym aksjologicznym Ja absolutem dla samego siebie, [...] Z głębi swego serca domaga się absolutnego uznania od strony innego" ${ }^{33}$. Można więc przyjąć, iż tolerancja jest wartością pozytywną, która czyni ludzkość wolną od uprzedzeń, wyzbywając się stygmatyzacji względem odmienności. Dzięki temu stajemy się społeczeństwem otwartym, zdolnym do dostrzegania pozytywów tkwiących w obcej kulturze. Potrafimy przenieść je do własnej, przy jednoczesnym zachowaniu swoistej, wielopokoleniowej tradycji. Jednak potencjał ten wymaga patrzenia na inność z perspektywy indywidualnego przywiązania do wartości rdzennych. Dlatego trzeba uczyć tolerancji, gdyż w swym aksjologicznym wymiarze czyni ona ludzkość wolną od stereotypów, ale należy też zachować dystans w jej praktykowaniu, tak aby otwierając się na różnorodność, nie doprowadzić do upadku indywidualnych zasad moralnych.

\section{Postawa tolerancji jako cel edukacji międzykulturowej}

Edukacja międzykulturowa pozwala ludzkości otworzyć się na cywilizacyjną różnorodność, wzbogacając tym samym repertuar rodzimych dóbr kultury o nowe doświadczenia, osadzone w kontekście własnej tradycji. Jej rola centralizuje się wokół problemu utrzymania jedności europejskich społeczeństw z uwzględnieniem i poszanowaniem ich kulturowego zróżnicowania, co podkreślone zostało m.in. w zapisach dokumentów źródłowych, określonych przez Radę Europy oraz w raporcie UNESCO - Jacques'a Delorsa (szerzej problem omawia Alina Szczurek-Boruta $)^{34}$.

Jej celem jest wychodzenie poza kanony odrębności, ponad granice społecznie utrwalonych norm i wzorców funkcjonujących w „świecie zakorze-

31 E. Podrez: Moralna ocena tolerancji. Tolerancja negatywna i pozytywna. W: A. Borowiak, P. Szarota (red.): Tolerancja i Wielokulturowość. Wyzwania XXI wieku. cyt. wyd., s. 23.

32 Tamże, s. 50.

33 Podaję za: I. Rudek: Od niechęci do akceptacji. O wychowaniu dzieci do tolerancji wobec osób niepetnosprawnych. cyt. wyd., s. 80.

34. A. Szczurek-Boruta: Edukacja i odkrywanie tożsamości w warunkach wielokulturowości. Szkice pedagogiczne. Katowice - Cieszyn - Kraków 2007, Oficyna Wydawnicza „Impuls”, s. 29. 
nienia", przy jednoczesnym podtrzymaniu wartości rdzennych ${ }^{35}$. Ważny jest tutaj aspekt komunikacji międzykulturowej, który obejmuje komunikację wpoprzekkulturowa (w obrębie jednej kultury), pomiędzykulturową (dialog uczestników różnych kultur) oraz międzynarodową (porozumiewanie się instytucji należących do różnych kultur) ${ }^{36}$. Natomiast założenia edukacji wielo- i międzykulturowej, zdaniem Beaty Kozieł, koncentrują się na: poznaniu Innego, dialogu z drugim człowiekiem, zaufaniu oraz kształtowaniu wartości wyższych, jak szacunek, tolerancja, a nade wszystko na doświadczaniu tożsamości, które wolne jest od dyskryminacji i uprzedzeń ${ }^{37}$. W związku z powyższym stawia ona sobie za zadanie respektowanie odmienności kulturowej współczesnych społeczeństw, przy jednoczesnym zniesieniu podziału na cywilizacje wyższe i niższe ${ }^{38}$. Koncentruje się zatem na kształtowaniu otwartości wobec świata obcych i wzbogacaniu repertuaru własnej kultury o nowe doświadczenia. Dlatego też edukacja międzykulturowa skupia się na dziecku, jego indywidualnych potrzebach i możliwościach, ukierunkowując i przygotowując uczniów do pełnego uczestnictwa w życiu społeczeństwa wielokulturowego ${ }^{39}$. Poprzez to warunkuje ona nabywanie tożsamości kulturowej, wpisanej zarówno w proces wychowania, jak i samowychowania, dążącego

35 J. Nikitorowicz: Wartości etosu jako podstawa kształtowania tożsamości wielokulturowej, podtoże konfliktów kulturowych i cel edukacji międzykulturowej. W: T. Lewowicki, E. Ogrodzka-Mazur, A. Gajdzica (red.): Świat wartości i edukacja międzykulturowa. Cieszyn - Warszawa 2003, UŚ - Filia w Cieszynie, Wyższa Szkoła Pedagogiczna ZNP w Warszawie, s. 44.

36 U. Michalik: Kształtowanie świadomości kulturowej oraz poprawianie komunikacji międzykulturowej jako niezbędny element edukacji w dobie globalizacji. W: A. Sajdak (red.): Kultura jako fundament wspólnoty edukacyjnej. Kraków 2005, UJ, s. 99.

37 B. Kozieł: Kształtujemy poczucie zakorzenienia w kulturze i postawy społeczne wobec Innego (przeciwdziałamy stereotypom i uprzedzeniom, budujemy postawy tolerancyjne). W: T. Lewowicki, J. Suchodolska (red.): Dzieci i młodzież w procesie kształtowania postaw kulturowych. Przewodnik po ścieżkach edukacji regionalnej, wielo- $i$ międzykulturowej. Cieszyn - Warszawa - Kraków 2012, Oficyna Wydawnicza „Impuls”, s. 17.

38 A. Szczęsna: Tożsamość przyszłych pedagogów $w$ aspekcie edukacji międzykulturowej. W: G. Gajewska, A. Szczęsna, E. Rewińska: Wychowanie do tolerancji. Teoretyczno-metodyczne aspekty warsztatu pedagoga. cyt. wyd., s. 41.

39 D. Misiejuk: Modyfikacja postaw wobec odmienności-rozważania. W: J. Kłoczkowski, S. Łukasiewicz (red.): Tożsamość, odmienność, tolerancja a kultura pokoju. Lublin 1998, Wydawnictwo Instytutu Europy Środkowowschodniej, s. 393. 
do dialogu, negocjacji i edukacyjnej równości w zakresie wielokulturowych reprezentantów ${ }^{40}$. Wobec powyższego do jej zadań należą m.in.: uczenie się kultury swojej i obcej; wzajemne jej wzbogacanie, zwracanie uwagi na problemy natury etnicznej czy wyznaniowej, tolerancja, poszanowanie odrębności innych kultur, zwiększanie poczucia wartości własnej grupy etnicznej oraz walka z uprzedzeniami (szerzej problem omawia J. Nikitorowicz) ${ }^{41}$. Należy podkreślić, że równorzędne zadanie w tym zakresie pełni rodzina i szkoła, a nade wszystko nauczyciele. Współuczestnicząc w procesie socjalizacji dziecka, warunkują oni nie tylko przyswajanie społecznie akceptowanych norm i zachowań, lecz także tożsamość kulturową jednostki. W jej ustaleniu istotną rolę odgrywają więzi, stanowiące moralne ramy ludzkości oraz proces identyfikacji ${ }^{42}$.

Tolerancja jest w tej relacji swoistym „łącznikiem” pomiędzy stereotypami wyniesionymi z domu oraz innowacjami docierającymi z innych kultur. Stanowi ona zatem podstawową wartość moralną, która uczy jednostkę obiektywnie patrzeć na otaczającą rzeczywistość, warunkując jej rozwój osobowościowy. Mały człowiek, akceptując zachodzące wokół niego zmiany, staje się ciekawy świata, otwarty na drugą osobę, wrażliwy na piękno i tolerancyjny wobec odmienności. Natomiast jej formułowanie w sposobie bycia dziecka w młodszym wieku szkolnym jest uwarunkowane istnieniem trzech komponentów: emocjonalno-oceniającego, poznawczego oraz behawioralnego ${ }^{43}$. Ich obecność - w ujęciu Tadeusza Pilcha - sprawia, że tolerancja urasta do rangi mechanizmu regulującego proces wychowania społecznego oraz rozwoju emocjonalnego i intelektualnego człowieka, co nadaje jej atrybuty „cechy nabywanej"44. Wymienione powyżej składniki kształtują dziecięcą kompetencję w zakresie zachowań tolerancyjnych, łącząc w sobie wartości egzystencjalne

40 J. Nikitorowicz: Pogranicze. Tożsamość. Edukacja międzykulturowa. Białystok 1995, Wydawnictwo Uniwersyteckie „Trans Humana”, s. 121.

41 Tamże.

42 A. Szczurek-Boruta: Edukacja i odkrywanie tożsamości w warunkach wielokulturowości. cyt. wyd., s. 64.

43 E. Ogrodzka-Mazur: Kompetencja aksjologiczna dzieci w mtodszym wieku szkolnym. Studium porównawcze środowisk zróżnicowanych kulturowo. Katowice 2007, UŚ, s. 110.

44 T. Pilch: Tolerancja-wartość społeczna i cnota indywidualna. W: J. Kłoczkowski, S. Łukasiewicz (red.): Tożsamość, odmienność, tolerancja a kultura pokoju. cyt. wyd., s. 119. 
(podmiotowość, godność, szacunek) oraz typy tolerancji opisującej, oceniającej, wyjaśniającej i postulatywnej (przewidującej) ${ }^{45}$. Dzięki nim człowiek może nawiązać dialog z obcym i jest zdolny do dokonywania rzeczywistych wyborów w zakresie wartości posiadanych i przyjmowanych z innych kultur. Dlatego też tolerancja jest postawą otwartości wobec interkulturowego dialogu.

\section{Poziom tolerancji dziecka w młodszym wieku szkolnym w opiniach nauczycieli edukacji wczesnoszkolnej}

Tolerancja jest jedną z podstawowych wartości moralnych w życiu każdego człowieka, a przede wszystkim w kształtowaniu się osobowości małego dziecka. Najczęściej przejawia ono „naiwną, bezrefleksyjną, pierwotną postać tej cechy i do tolerancji prawdziwej droga jeszcze daleka"46. W dobie kulturowego zróżnicowania oraz transmisji wartości ogólnoludzkich niezwykle ważna jest kwestia wychowania do tolerancji, realizowanego zwłaszcza w warunkach szkolnych. Zgodnie z założeniami Nowej Ustawy Programowej jednym z celów edukacji wczesnoszkolnej jest kształtowanie świadomości społecznej dziecka, w tym jego przynależności do rodziny, grupy rówieśniczej i wspólnoty narodowej ${ }^{47}$. Natomiast w zakresie treści etycznych rozumie ono, że ludzie są równi bez względu na wygląd, wyznanie, status materialny lub miejsce urodzenia ${ }^{48}$. Nauczyciele, jako wychowawcy, na tym etapie staja się moralnymi przewodnikami oraz obiektywnymi obserwatorami wszelkich postaw, jakie mały człowiek przyjmuje wobec otoczenia w kolejnych etapach swego uspołeczniania. Kwestia ta nabiera szczególnej rangi wobec zaznaczonej obecnie coraz silniej socjalizacji permanentnej, w obrębie której zachodzi interioryzowanie nowych wzorców kulturowych ${ }^{49}$. Powołując się w tym miejscu na stanowisko Aliny Szczurek-Boruty, iż Górny Śląsk jest regionem

45 E. Ogrodzka-Mazur: Kompetencja aksjologiczna dzieci w młodszym wieku szkolnym. Studium porównawcze środowisk zróżnicowanych kulturowo. cyt. wyd., s. 110-111.

46 A. Godlewska: Inny nie znaczy gorszy. „Życie Szkoły” 2011, nr 6, s. 43.

47 http://www.bip.men.gov.pl/men_bip/akty_prawne/rozporzadzenie_20081223_ zal_2.pdf (3.10.2012).

48 Tamże.

49 P. Sztompka: Socjologia. Analiza społeczeństwa. Kraków 2003, Wydawnictwo „Znak”, s. 416. 
stanowiącym kulturowy tygiel, w obrębie którego pielęgnowane są rodzime tradycje ${ }^{50}$, można stwierdzić, że sytuacja ta implikuje proces wychowania, przenosząc do niego czynniki zaczerpnięte z innych kultur, które następnie zostają przyswojone przez socjalizowaną jednostkę ludzką. Wobec tego tolerancja na etapie edukacji wczesnoszkolnej stanowi wartość konieczną w drodze do międzykulturowego dialogu przyszłych pokoleń.

Celem podjętych badań własnych było poznanie poziomu tolerancji, jaki przejawiają dzieci w młodszym wieku szkolnym, oraz czynników, które ją warunkują. W postępowaniu empirycznym wykorzystałam metodę sondażu diagnostycznego, która zgodnie ze stanowiskiem M. Łobockiego polega na gromadzeniu informacji w zakresie interesujących badacza problemów, uzyskiwanych na podstawie wypowiedzi respondentów ${ }^{51}$. Wobec powyższego wykorzystałam technikę ankiety, która jest formą gromadzenia danych za pomocą zestawu pytań ${ }^{52}$. W celu określenia poziomu tolerancji dzieci w młodszym wieku szkolnym posłużyłam się samodzielnie skonstruowanym kwestionariuszem ankiety dla nauczyciela edukacji wczesnoszkolnej, który zawierał pytania w formie zamkniętej, półotwartej i otwartej.

Badania zostały przeprowadzone na przełomie kwietnia i maja 2012 roku, na terenie dwóch miejscowości powiatu wodzisławskiego (Pszowa i Gorzyczek), wchodzącymi w obszar województwa śląskiego. Wybór terenu badań był celowy, gdyż zarówno Pszów, jak i Gorzyce są miejscowościami zróżnicowanymi kulturowo o silnie zakorzenionych tradycjach górniczych i religijnych, co w znaczącym stopniu warunkuje kształtowanie poziomu tolerancji w postawach wzrastających w nich jednostek. Procesem badawczym objęto wówczas nauczycieli zintegrowanej edukacji wczesnoszkolnej powyższych szkół oraz nauczycieli wspomagających z oddziałów integracyjnych.

Podczas przeprowadzenia badań podjęłam próbę oceny stopnia tolerancji przejawianego przez dzieci w młodszym wieku szkolnym. W jego dookreśleniu wykorzystałam skalę ocen (niedostateczny, dostateczny, dobry i bardzo dobry). Uzyskane dane empiryczne ukazały, iż znaczna liczba respondentów $(\mathrm{N}=33 \%)$ wskazała na niedostateczny poziom tolerancji dziecka w młodszym

50 A. Szczurek-Boruta: Edukacja wobec transmisji i transformacji wartości-kilka refleksji dotyczacych młodzieży z Górnego Ślaska. W: T. Lewowicki, E. Ogrodzka-Mazur, A. Gajdzica (red.): Świat wartości i edukacja międzykulturowa. cyt. wyd., s. 245.

51 M. Łobocki: Wprowadzenie do metodologii badań pedagogicznych. Kraków 2010, Oficyna Wydawnicza „Impuls”, s. 217.

52 Tamże, s. 264. 
wieku szkolnym. W granicy dobrego wyodrębniono aż 38\% wskazań badanych, a $21 \%$ opowiedziało się za dostatecznym stopniem tolerancji. Najmniejsze wartości odnotowano dla oceny bardzo dobrej $(\mathrm{N}=8 \%)^{53}$.

Zróżnicowanie poziomu tolerancji dzieci w młodszym wieku szkolnym było uwarunkowane udziałem w badaniach nauczycieli szkoły zawierającej w swej strukturze oddziały integracyjne. W związku z powyższym integracja z uczniami o znacznym lub umiarkowanym stopniu niepełnosprawności stanowiła tutaj jeden $\mathrm{z}$ wielu branych pod uwagę wyznaczników inności. Dlatego też podjęto próbę określenia, jakie jest zróżnicowanie stopnia tolerancji wśród dzieci w młodszym wieku szkolnym ze względu na typ placówki ogólnodostępnej i integracyjnej w świetle ocen nauczycieli. Na podstawie uzyskanych opinii zauważono, że wyższy stopień tolerancji uzyskały dzieci w młodszym wieku szkolnym, które uczęszczały do szkoły integracyjnej, w porównaniu do uczniów szkoły ogólnodostępnej.

Nauczyciele ze szkoły integracyjnej w większości dokonali ocen na poziomie dobrym $(\mathrm{N}=75 \%)$ i bardzo dobrym $(\mathrm{N}=18 \%)$, a znikoma liczba badanych $(\mathrm{N}=8 \%)$ uznała go za dostateczny. Nikt z respondentów nie określił stopnia tolerancji dzieci w młodszym wieku szkolnym jako niedostatecznego, podczas gdy nauczyciele szkół ogólnodostępnych nie uwzględnili oceny bardzo dobrej. Stopień tolerancji wśród dzieci w młodszym wieku szkolnym w placówce ogólnodostępnej w opiniach respondentów jest odpowiedni do wskazań: niedostateczny $(\mathrm{N}=42 \%)$, dostateczny $(\mathrm{N}=26 \%)$ oraz dobry $(\mathrm{N}=32 \%)$. Rozbieżność w powyższych wynikach ukazuje, iż integracja podwyższa poziom tolerancji dzieci w młodszym wieku szkolnym. Przekłada się to również na większą akceptację dziecka niepełnosprawnego względem samego siebie oraz wykreowanie wartościowego obrazu swej osoby. W warunkach izolacji byłoby to trudne do osiągnięcia. Uczestnictwo w życiu szkoły osób niepełnosprawnych uczy obiektywnego spojrzenia na życie, chorobę i odmienność. Dla dziecka w młodszym wieku szkolnym jest to lekcja, jak stać się otwartym na inność, tolerancyjnym człowiekiem, wolnym od prowadzących do nietolerancji stereotypów i uprzedzeń.

Dlatego, aby dokładniej sprecyzować czynniki warunkujące zachowania nietolerancyjne wśród dzieci w młodszym wieku szkolnym, poproszono an-

53 Przywołuję wyniki badań przeprowadzonych przez Justynę Ryszewską-Banko: Problem tolerancji wśród uczniów klas poczatkowych. Łódź 2012, AHE, Wydział Zamiejscowy w Wodzisławiu Śląskim. Praca dyplomowa przygotowana pod kierunkiem dr Barbary Grzyb. 
kietowanych nauczycieli o wytypowanie cech i wartości, które w ich opiniach implikują ujawnienie postaw nietolerancji wśród dzieci w młodszym wieku szkolnym. Przyjęto za Tadeuszem Pilchem, że zarówno tolerancja, jak i nietolerancja są kategoriami pojęciowymi nieobojętnymi dla procesu edukacji, opierającymi się na archetypie obcości (odmienne obyczaje, wyznanie, przynależność rasowa, etniczna, ubiór, choroba), wpisanymi w świat zachowań społecznych oraz moralności ${ }^{54}$. Powyższe założenie dało podstawę do sformułowania sześciu kategorii pojęciowych, w oparciu o które ankietowani nauczyciele dokonywali swych wyborów.

Wśród czynników warunkujących nietolerancję dziecka w młodszym wieku szkolnym badani wytypowali następujące ich kategorie pojęciowe: niepełnosprawność ( $\mathrm{N}=35 \%)$, odmienny styl ubierania się $(\mathrm{N}=24 \%)$, zła sytuacja materialna rodziny $(\mathrm{N}=21 \%)$ oraz inna wiara $(\mathrm{N}=17 \%)$. Znikoma liczba respondentów ( $\mathrm{N}=3 \%$ ) opowiedziała się za kolorem skóry. Nikt z ankietowanych nie wytypował bogactwa jako czynnika sprzyjającego nietolerancji. Z wyborów tych wyłonił się obraz jednostki nietolerancyjnej, która patrzy na inność w kategoriach: posiadania, ubioru, koloru skóry czy możliwości psychofizycznych człowieka. Walory te zajmują nadrzędną pozycję w budowaniu relacji w grupie rówieśniczej, determinując postawę nieakceptacji, wrogość, a nawet przejawy agresji.

Opierając się na założeniu, że postawa tolerancji nie jest uwarunkowana genetycznie, lecz stanowi skutek wychowawczy, na który składa się szereg oddziaływań środowiska wychowawczego, m.in. rodziny, szkoły i grupy rówieśniczej ${ }^{55}$, podjęto próbę dookreślenia form reakcji nauczycieli edukacji wczesnoszkolnej wobec zachowań nietolerancyjnych przejawianych przez dzieci w młodszym wieku szkolnym. W związku z tym poproszono respondentów o opinie w tej kwestii.

Na podstawie uzyskanych wyników można zauważyć, że większość ankietowanych nauczycieli stara się negować dziecięce postawy nietolerancji, podejmując rozmowę o tolerancji $(\mathrm{N}=64 \%)$ oraz poprzez postawienie ucznia w sytuacji rówieśnika nieakceptowanego $(\mathrm{N}=18 \%)$. Niewielka liczba badanych $(\mathrm{N}=9 \%)$ opowiedziała się $\mathrm{w}$ równej mierze za indywidualnym upomnie-

54 T. Pilch: Tolerancja-wartość społeczna i cnota indywidualna. W: J. Kłoczkowski, S. Łukasiewicz (red.): Tożsamość, odmienność, tolerancja a kultura pokoju. cyt. wyd., S. 119.

55 J. Hanisz: Tolerowanie dzieci niepetnosprawnych. W: A. Rosół, M. S. Szczepański (red.): Tolerancja. Studia i szkice. T. III. Częstochowa 1996, WSP, s. 47. 
niem ucznia zachowującego się nietolerancyjnie oraz stosowaniem metod i technik nauczania (zabawy, ćwiczenia, ankiety socjoterapeutyczne). Powyższy wynik wskazuje, że nauczyciele są wyczuleni na wszelkie zaistniałe przejawy nietolerancji w zachowaniu dzieci w młodszym wieku szkolnym. Jednak istotną przeszkodą praktyczną jest tutaj nadmierne przeładowanie programów edukacyjnych treściami przedmiotowymi, co ogranicza czasowo realizację edukacji ku tolerancji w technik nauczania, co również zostało podkreślone w opiniach ankietowanych.

\section{Podsumowanie}

Przedstawione wyniki badań w zakresie stopnia tolerancji ukazały, że pomimo jej lokowania na wysokiej pozycji w zakresie wartości realizowanych w wychowaniu i nauczaniu, dzieci w młodszym wieku szkolnym przejawiają niski jej poziom. Wśród czynników ją determinujących istotną rolę pełni integracja z osobami niepełnosprawnymi, która uwrażliwia na kwestię akceptacji, pomimo różnic indywidualnych. Zarówno szkoła, jak i nauczyciele odgrywają znaczącą rolę w socjalizacji dziecka w młodszym wieku szkolnym, warunkując kształtowanie postaw tolerancji poprzez poświęcanie jej jak najwięcej miejsca w realizowanych przez siebie treściach edukacyjnych. Uzyskane w trakcie badań konkluzje uwydatniły również czynniki implikujące nietolerancję dziecka w młodszym wieku szkolnym, jak kolor skóry, wyznanie czy status materialny.

Podsumowując, należy zatem podkreślić, iż kwestia edukacji ku tolerancji w obecnej rzeczywistości „świata bez granic” jest wciąż aktualnym problemem. Dlatego współczesna szkoła powinna głównie ukierunkowywać uczniów na przyjmowanie postawy akceptacji nie tylko wobec niepełnosprawnych, ale również względem ludzi innego wyznania czy narodowości, posiadających odmienną kulturę. Jednak zróżnicowanie to często staje się przyczyną uprzedzeń. Zatem ucząc dzieci zasad tolerancji, wdrażając je do przejawiania zachowań protolerancyjnych, umożliwiamy im życie w społeczeństwie otwartym, opartym na zasadzie rozumnej akceptacji, wolności i szacunku. Dostrzeganie pozytywnego aspektu inności jest tutaj gwarantem budowania świata, w którym nie ma podziału na lepszych i gorszych, równych i równiejszych. Dlatego też cele edukacji międzykulturowej nawiązują do idei tolerancji, gdyż wychodzą ponad podziały, tworząc jedność w wymiarze społecznym, kulturowym oraz wyznaniowym. Tolerowanie staje się tutaj 
warunkiem koniecznym na drodze do tworzenia liberalnego modelu społeczeństwa otwartego na globalną różnorodność kultur, gdyż ludzka tolerancja rodzi się tam, gdzie zaczyna się różnorodność.

\section{Bibliografia}

Borowiak A., Szarota P. (red.): Tolerancja i wielokulturowość. Wyzwania XXI wieku. Warszawa 2004, SWPS „Academica”.

Gajewska G., Szczęsna A., Rewińska E.: Wychowanie do tolerancji. Teoretyczno-metodyczne aspekty warsztatu pedagoga. Zielona Góra 2006, PEKW "GAJA".

Godlewska A.: Inny nie znaczy gorszy. „Życie Szkoły” 2011, nr 6.

Górniewicz J.: Kategorie pedagogiczne. Olsztyn 2001, UWM

Hamer H.: Demon Nietolerancji. Warszawa 1994,WSiP.

http://www.bip.men.gov.pl/men_bip/akty_prawne/rozporzadzenie_2008 1223_zal_2.pdf.

Kłoczkowski J., Łukasiewicz S. (red.): Tożsamość, odmienność, tolerancja a kultura pokoju. Lublin 1998, Instytut Europy Środkowo-Wschodniej.

Kopińska V.: Kilka uwag o tolerancji. „Wychowanie na co dzień” 2008, nr 3.

Krajewski R.: Czy katolik może być tolerancyjny. „Znak” 2007, nr 11.

Lewowicki T., Ogrodzka-Mazur E., Gajdzica A. (red.): Świat wartości i edukacja międzykulturowa. Cieszyn - Warszawa 2003, UŚ - Filia w Cieszynie, Wyższa Szkoła Pedagogiczna ZNP w Warszawie.

Lewowicki T., Suchodolska J. (red.): Dzieci i młodzież w procesie kształtowania postaw kulturowych. Przewodnik po ścieżkach edukacji regionalnej, wielo- $i$ międzykulturowej. Cieszyn - Warszawa - Kraków 2012, Oficyna Wydawnicza „Impuls”.

Łobocki M.: W trosce o wychowanie w szkole. Kraków 2009, Oficyna Wydawnicza „Impuls”.

Łobocki M.: Wprowadzenie do metodologii badań pedagogicznych. Kraków 2010, Oficyna Wydawnicza „Impuls”.

Mazurkiewicz P.: Tolerancja błogosławieństwo czy przekleństwo. „Społeczeństwo Otwarte" 1996, nr 10.

Młynarczuk A., Sokołowski M. M.: Ze sobq, a nie obok siebie (edukacja równoległa w procesie kształtowania postaw tolerancji. „Nowa Szkoła” 2008, nr 5 . 
Nikitorowicz J.: Pogranicze. Tożsamość. Edukacja międzykulturowa. Białystok 1995, Wydawnictwo Uniwersyteckie „Trans Humana”.

Nikitorowicz J.: Tolerancja idea i cel edukacji międzykulturowej. „Problemy Opiekuńczo-Wychowawcze" 1995, nr 6.

Ogrodzka-Mazur E.: Kompetencja aksjologiczna dzieci w młodszym wieku szkolnym. Studium porównawcze środowisk zróżnicowanych kulturowo. Katowice 2007, UŚ.

Okoń W:: Nowy słownik pedagogiczny. Warszawa 1998, Wydawnictwo Akademickie „Żak”.

Rosół A., Szczepański M.: Tolerancja. Studia i szkice. T. IV. Częstochowa 1997, nr 4.

Rosół A., Szczepański M. S. (red.): Tolerancja. Studia i szkice. T. III. Częstochowa 1996, WSP.

Rudek I.: Od niechęci do akceptacji. O wychowaniu dzieci do tolerancji wobec osób niepetnosprawnych. Kraków 2008, Oficyna Wydawnicza „Impuls”.

Sajdak A. (red.): Kultura jako fundament wspólnoty edukacyjnej. Kraków 2005, UJ.

Szczurek-Boruta A.: Edukacja i odkrywanie tożsamości w warunkach wielokulturowości. Katowice - Cieszyn - Kraków 2007, Oficyna Wydawnicza „Impuls".

Szewetowska K.: Tolerancja - zjawisko społeczne czy postawa? „Edukacja i Dialog" 2007, nr 5.

Sztompka P: Socjologia. Analiza społeczeństwa. Kraków 2003, „Znak”.

Walzer M.: O tolerancji. Warszawa 1999, PIW.

Wysocka E.: Religijność a tolerancja. Obszary zależności. Kraków 2000, „Nomos".

\section{Tolerance as a value and aim in multi- and intercultural education of the child at early school age}

\section{Summary}

The question of education for tolerance in the current reality of a world without borders is still a current issue. It is a priority in the education objectives of the multi-and intercultural communication. Thus we are becoming an open society. Therefore, in this article are discussed issues relating to the concept of tolerance, its ranges and dimensions with regard to intercultural education. On the basis 
of the obtained opinions of teachers, the problem is undertaken of young age children's tolerance in terms of expressing the child's attitudes pro and contra tolerance.

Key words: tolerance, multicultural and intercultural education

Translated by Justyna Ryszewska-Banko 